\title{
Glutamate-mediated effects of caffeine and interferon- $\gamma$ on mercury-induced toxicity
}

\author{
AYSE BASAK ENGIN $^{1}$, EVREN DORUK ENGIN ${ }^{2}$, KIRILL GOLOKHVAST $^{3}$, \\ DEMETRIOS A. SPANDIDOS ${ }^{4}$ and ARISTIDES M. TSATSAKIS ${ }^{5}$
}

\begin{abstract}
${ }^{1}$ Department of Toxicology, Faculty of Pharmacy, Gazi University, Ankara 06330; ${ }^{2}$ Institute of Biotechnology, Ankara University, Ankara 06110, Turkey; ${ }^{3}$ Scientific Educational Center of Nanotechnology, Far Eastern Federal University, Engineering School, Vladivostok 690950, Russia; ${ }^{4}$ Laboratory of Clinical Virology, Medical School, University of Crete; ${ }^{5}$ Department of Forensic Sciences and Toxicology, Faculty of Medicine, University of Crete, Heraklion 71003, Greece
\end{abstract}

Received January 9, 2017; Accepted March 13, 2017

DOI: 10.3892/ijmm.2017.2937

\begin{abstract}
The molecular mechanisms mediating mercury-induced neurotoxicity are not yet completely understood. Thus, the aim of this study was to investigate whether the severity of $\mathrm{MeHg}$ - and $\mathrm{HgCl}_{2}$-mediated cytotoxicity to SH-SY5Y human dopaminergic neurons can be attenuated by regulating glutamate-mediated signal-transmission through caffeine and interferon- $\gamma$ (IFN- $\gamma$ ). The SH-SY5Y cells were exposed to 1,2 and $5 \mu \mathrm{M}$ of either $\mathrm{MeHgCl}_{2}$ or $\mathrm{HgCl}_{2}$ in the presence or absence of L-glutamine. To examine the effect of adenosine receptor antagonist, the cells were treated with 10 and $20 \mu \mathrm{M}$ caffeine. The total mitochondrial metabolic activity and oxidative stress intensity coefficient were

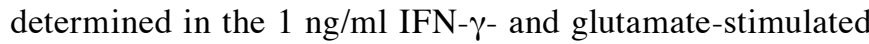
SH-SY5Y cells. Following exposure to mercury, the concentration-dependent decrease in mitochondrial metabolic activity inversely correlated with oxidative stress intensity. $\mathrm{MeHg}$ was more toxic than $\mathrm{HgCl}_{2}$. Mercury-induced neuronal death was dependent on glutamate-mediated excitotoxicity. Caffeine reduced the mercury-induced oxidative stress in glutaminecontaining medium. IFN $-\gamma$ treatment decreased cell viability and increased oxidative stress in glutamine-free medium, despite caffeine supplementation. Although caffeine exerted a protective effect against $\mathrm{MeHg}$-induced toxicity with glutamate transmission, under co-stimulation with glutamine and IFN- $\gamma$, caffeine decreased the MeHg-induced average oxidative stress only by half. Thereby, our data indicate that the IFN- $\gamma$ stimulation of mercury-exposed dopaminergic neurons in neuroinflammatory diseases may diminish the neuroprotective effects of caffeine.
\end{abstract}

Correspondence to: Dr Ayse Basak Engin, Department of Toxicology, Faculty of Pharmacy, Gazi University, Hipodrom, Ankara 06330, Turkey

E-mail: abengin@gmail.com

Key words: methyl mercury, mercury chloride, caffeine, interferon- $\gamma$, neurotoxicity, glutamine

\section{Introduction}

Mercury exposure is linked to a shift in the redox status toward oxidative stress. It may enhance lipid peroxidation in all tissues and may have deleterious effects on an organism (1). As MeHg easily crosses the blood-brain barrier, it is highly neurotoxic in exposed human populations (2). Therefore, its cytotoxic effect on neurons is stronger when compared to inorganic $\mathrm{HgCl}_{2}$, even at low levels (3). Eventually, $\mathrm{MeHg}$ administration reduces non-enzymatic and enzymatic antioxidants (6).

Mercury has been shown to affect several aspects of glutamatergic signaling (4). In this context, MeHg markedly increases the glutamate concentration at the synaptic cleft by enhancing spontaneous glutamate release from neurons (5). Eventual excitotoxic activity of glutamate resulting from $\mathrm{MeHg}$ exposure contributes to neuronal injury. N-methyl-D-aspartate (NMDA) receptor-binding memantine attenuates MeHg-induced neurotoxicity (6). It has also been shown that the $\mathrm{HgCl}_{2}$-induced reduction of cell viability is substantially attenuated by the application of a non-competitive antagonist of NMDA receptors (7). Although mercury-induced neuronal degeneration is suggested to invoke glutamate-mediated excitotoxicity, the underlying mechanisms remain poorly understood.

Caffeine is the most widely consumed psychoactive substance and acts as an antagonist of adenosine A1 and A2A receptors at non-toxic doses (8). Although A1 receptors are located pre-synaptically on dopaminergic, glutamatergic and cholinergic inputs to neurons, Brown et al could not detect any evidence regarding the effect of caffeine on mercury-induced toxicity (9).

On the other hand, mercury-exposed rats have been shown to exhibit enhanced interferon- $\gamma$ (IFN- $\gamma$ ) serum levels as compared to the controls (10). Furthermore, it is claimed that vascular endothelial growth factor and interleukin-6 (IL-6) are released from human mast cells via the stimulation of mercury and disrupt the blood-brain-barrier and permit brain inflammation (11). In neurodegenerative diseases, brain inflammation and the facilitated entrance of immune cells through the blood-brain barrier can potentially cause neuronal damage and cognitive dysfunction $(12,13)$. Thus, the disruption of the blood-brain barrier allows the infiltration of immune 
cells to the brain and enhances the responsiveness of neurons to IFN- $\gamma$ (14). T-cell traffic across the blood-brain barrier considerably increases, thereby exposing neuronal cells to the potent effects of IFN- $\gamma$ (15). Eventually, IFN- $\gamma$ acts directly on neural cells $(16,17)$, and causes neurodegenerative alterations in the central nervous system (CNS) (18). Nevertheless, the precise role of IFN- $\gamma$ during neuro-inflammation remains unclear (19). Mizuno et al suggested that IFN- $\gamma$ synergistically enhances glutamate neurotoxicity mediated by $\alpha$-amino-3-hy droxy-5-methyl-4-isoxazolepropionic acid (AMPA) receptors, but not NMDA receptors (20). By contrast, Lee et al previously indicated that IFN- $\gamma$-mediated neuroprotection is associated with an enhanced recovery of intracellular $\mathrm{Ca}^{2+}$ concentrations following exposure to glutamate (21). In this manner, conflicting results have been presented regarding the effect of IFN- $\gamma$ on glutamate-induced signaling. Furthermore, there is less information available on the association between mercury-induced cytotoxicity and caffeine or IFN- $\gamma$ during the presence or absence of glutamine.

Thus, the aim of the present study was primarily to investigate whether mercury-induced neuronal damage is associated with glutamatergic excitotoxicity, and secondly, to determine whether glutamate signal transmission participates in the alteration of mercury-induced neurotoxicity through caffeine and IFN- $\gamma$.

\section{Materials and methods}

Cell culture. The human neuroblastoma cell line, SH-SY5Y, was cultured in EMEM:F12 (1:1) (Biochrom GmbH, Berlin, Germany) supplemented with $15 \%$ fetal bovine serum (FBS; Biochrom $\mathrm{GmbH}$ ) at $37^{\circ} \mathrm{C}, 5 \% \mathrm{CO}_{2}$. The cells were divided into 2 groups and cultured in either $292 \mathrm{mg} / 1 \mathrm{~L}$-glutamine containing or L-glutamine free-medium. All the experiments were run in both cell groups. The solutions of 1,2 and $5 \mu \mathrm{M}$ $\mathrm{MeHgCl}_{2}$ and $\mathrm{HgCl}_{2}$ (Merck KGaA, Darmstadt, Germany), 10 and $20 \mu \mathrm{M}$ caffeine (Sigma-Aldrich, St. Louis, MO, USA) were prepared in L-glutamine-supplemented or glutamine-free medium (Biochrom $\mathrm{GmbH}$ ) and sterilized using a $0.2 \mu \mathrm{m}$ syringe filter (Fuxing Pharmaceutical Co., Ltd., Shanghai, China). Experiments were repeated under either $1 \mathrm{ng} / \mathrm{ml}$ human IFN- $\gamma(\mathrm{hIFN}-\gamma)$-containing or hIFN- $\gamma$-free conditions.

Production of $h I F N-\gamma$. Active hIFN- $\gamma$ was produced by using a bacterial protein expression system. The pET28abased expression plasmid was constructed using the SLICE cloning procedure, as previously described (22). Briefly, codon optimized synthetic gene that encodes hIFN-g mature peptide (Uniprot accession P01579, amino acids between 24 and 161) was purchased from Macrogen, Inc. (Seoul, Korea). Escherichia coli BL21 cells were used as the expression host (Novagen Inc., Madison, WI, USA). pET expression system and expression host bacterium $E$. coli BL21 cells were obtained from Novagen Inc. (23). The cells were grown in $100 \mathrm{ml}$ of terriffic broth until a turbidity of 0.5 absorbance was reached at OD600. Subsequently, culture was induced by using $1 \mathrm{mM}$ IPTG (24). Following overnight expression, the cells were harvested and lysed using BPER reagent (Thermo Fisher Scientific, Waltham, MA, USA). IFN- $\gamma$ from cleared lysate was purified using immobilized nickel affinity chromatography (GE Healthcare, Piscataway, NJ, USA). Imidazole removal and a polishing step were performed using sephadex G25 (GE Healthcare) gel filtration chromatography, as previously described (25).

Experimental design. The SH-SY5Y human neuroblastoma cells $\left(10^{4}\right.$ cells/well) were seeded in 96 -well plates. Twenty four hours after seeding (one cell cycle), the cells were exposed to various concentrations of $\mathrm{HgCl}_{2}$ and $\mathrm{MeHgCl}_{2}$ in medium with or without $292 \mathrm{mg} / \mathrm{l} \mathrm{L}$-glutamine for either 24 or $48 \mathrm{~h}$. All the assays were performed in triplicates in 3 sets of experiments.

In this study, in order to clarify the mechanisms responsible for mercury-induced neuronal toxicity, we used two different substances in addition to the various concentrations of mercury compounds in SH-SY5Y cell cultures, caffeine and IFN- $\gamma$. The concentrations of mercury compounds and caffeine that were used in the experiments, were selected by the evaluation of possible exposure doses (26-30). The exposure duration was determined as one and two cell cycles. For further experiments, $10^{4}$ cells were seeded in 96-well plates in medium with or without $292 \mathrm{mg} / \mathrm{l} \mathrm{L}$-glutamine; each set was individually pre-incubated for $30 \mathrm{~min}$ with 10 or $20 \mu \mathrm{M}$ caffeine and after this period, 1,2 or $5 \mu \mathrm{M}$ of either $\mathrm{MeHgCl}_{2}$ or $\mathrm{HgCl}_{2}$ were added and the cells were incubated for 24 and $48 \mathrm{~h}$ in FBS-containing medium. Each set of experiments was repeated with cells pre-incubated with hIFN- $\gamma$. In all samples 3-(4,5-dimethylthiazol-2-yl)-2,5-diphenyltetrazolium bromide (MTT) assay was performed as described below. The cells were also counted using trypan blue dye (Sigma-Aldrich) for each time point and for each concentration in each assay condition.

Mitochondrial metabolic activity. Mitochondrial metabolic activity was assessed by MTT assay according to a modified method of Mosmann (31). Briefly, the cells were exposed to the compounds and MTT dye (Serva, Heidelberg, Germany) $(0.5 \mathrm{mg} / \mathrm{ml}$ in phosphate-buffered saline; Merck KGaA) was added to each well $4 \mathrm{~h}$ after the completion of the incubation period. Thereafter, the produced formazan crystals were solubilized by the addition of $10 \%$ SDS (Merck KGaA) in $1 \mathrm{~N} \mathrm{HCl}$ solution (Merck KGaA). The resultant absorbance was measured spectrophotometrically (VersaMax ELISA Microplate Reader; Molecular Devices, Sunnyvale, CA, USA) at $550 \mathrm{~nm}$ with the reference wavelength of $690 \mathrm{~nm}$.

Total nitrite and nitrate $\left(\right.$ Merck KGaA) $\left(\mathrm{NO}_{3}+\mathrm{NO}_{2} ; \mathrm{NOx}\right)$ levels were measured using the Griess method, as previously described (32). The oxidative stress intensity coefficient (Q) was calculated by dividing the NOx produced per cell (cell count; $\mathrm{Cc}$ ) to the total mitochondrial metabolic activity per cell (alteration in cell viability - MTT/Cc); Q = [(NOx/Cc)/MTT/Cc $](33)$.

Statistical analysis. The significance of the differences between the control and compound-treated cell groups were analyzed by a Student's t-test and a value of $\mathrm{P}<0.05$ was considered to indicate a statistically significant difference. The calculations were performed using the statistical package SPSS, version 13.0 (SPSS, Inc., Chicago, IL, USA).

\section{Results}

The effects of L-glutamine in caffeine-supplemented medium on the total mitochondrial metabolic activity and oxidative stress in mercury-exposed SH-SY5Y cells are shown in Tables I-IV. 
Table I. Oxidative stress intensity coefficient and total mitochondrial metabolic activity/viability of $\mathrm{MeHg}^{-}$and $\mathrm{HgCl}$-exposed SH-SY5Y human neuroblastoma cells at the end of the first 24-h incubation period with or without caffeine in glutamine-free medium.

\begin{tabular}{|c|c|c|c|c|c|c|}
\hline & \multicolumn{2}{|c|}{ Without caffeine } & \multicolumn{2}{|c|}{$10 \mu \mathrm{M}$ caffeine } & \multicolumn{2}{|c|}{$20 \mu \mathrm{M}$ caffeine } \\
\hline & MTT (\%) & $\mathrm{Q}(\mu \mathrm{M} / \%)$ & $\operatorname{MTT}(\%)$ & $\mathrm{Q}(\mu \mathrm{M} / \%)$ & $\operatorname{MTT}(\%)$ & $\mathrm{Q}(\mu \mathrm{M} / \%)$ \\
\hline Control & $99.4 \pm 0.16$ & $0.18 \pm 0.13$ & $114.7 \pm 1.33$ & $0.17 \pm 0.03$ & $100.3 \pm 0.15$ & $0.16 \pm 0.01$ \\
\hline $\mathrm{MeHg} 1 \mu \mathrm{M}$ & $91.9 \pm 0.18^{a}$ & $0.23 \pm 0.07$ & $98.5 \pm 0.58$ & $0.23 \pm 0.04$ & $92.1 \pm 0.54$ & $0.19 \pm 0.02$ \\
\hline $\mathrm{MeHg} 2 \mu \mathrm{M}$ & $94.4 \pm 0.51$ & $0.24 \pm 0.02$ & $94.1 \pm 0.42$ & $0.24 \pm 0.03$ & $94.8 \pm 0.92$ & $0.18 \pm 0.04$ \\
\hline $\mathrm{MeHg} 5 \mu \mathrm{M}$ & $56.0 \pm 1.02^{\mathrm{a}}$ & $0.35 \pm 0.04^{\mathrm{a}}$ & $57.8 \pm 1.87^{\mathrm{a}}$ & $0.26 \pm 0.01^{\mathrm{a}}$ & $44.4 \pm 1.14^{\mathrm{a}}$ & $0.43 \pm 0.22^{\mathrm{a}}$ \\
\hline $\mathrm{HgCl}_{2} 1 \mu \mathrm{M}$ & $104.3 \pm 0.47$ & $0.18 \pm 0.05$ & $99.1 \pm 0.21$ & $0.18 \pm 0.08$ & $114.2 \pm 2.11$ & $0.14 \pm 0.02$ \\
\hline $\mathrm{HgCl}_{2} 2 \mu \mathrm{M}$ & $104.8 \pm 0.01^{\mathrm{a}}$ & $0.23 \pm 0.06$ & $114.1 \pm 13.4$ & $0.16 \pm 0.04$ & $95.6 \pm 0.54$ & $0.15 \pm 0.00$ \\
\hline $\mathrm{HgCl}_{2} 5 \mu \mathrm{M}$ & $104.4 \pm 0.86$ & $0.19 \pm 0.04$ & $94.8 \pm 0.89$ & $0.19 \pm 0.02$ & $95.4 \pm 1.35$ & $0.22 \pm 0.04$ \\
\hline
\end{tabular}

${ }^{a} \mathrm{P}<0.05$, mercury-exposed cells vs. matched caffeine + mercury-exposed cells. MeHg, methyl mecury; Q:[(NOx/Cc)/(MTT/Cc)], oxidative stress coefficient; MTT, mitochondrial metabolic activity/cell viability.

Table II. Oxidative stress intensity coefficient and total mitochondrial metabolic activity/viability of $\mathrm{MeHg}^{-}$and $\mathrm{HgCl}_{2}$-exposed SH-SY5Y human neuroblastoma cells at the end of the second 24-h incubation period with or without caffeine in glutamine-free medium.

\begin{tabular}{|c|c|c|c|c|c|c|}
\hline & \multicolumn{2}{|c|}{ Without caffeine } & \multicolumn{2}{|c|}{$10 \mu \mathrm{M}$ caffeine } & \multicolumn{2}{|c|}{$20 \mu \mathrm{M}$ caffeine } \\
\hline & MTT (\%) & $\mathrm{Q}(\mu \mathrm{M} / \%)$ & $\operatorname{MTT}(\%)$ & $\mathrm{Q}(\mu \mathrm{M} / \%)$ & $\operatorname{MTT}(\%)$ & $\mathrm{Q}(\mu \mathrm{M} / \%)$ \\
\hline Control & $99.8 \pm 0.22$ & $0.23 \pm 0.16$ & $111.1 \pm 0.77$ & $0.15 \pm 0.05$ & $111.2 \pm 0.55^{\mathrm{a}}$ & $0.14 \pm 0.03$ \\
\hline $\mathrm{MeHg} 1 \mu \mathrm{M}$ & $100.2 \pm 0.35$ & $0.19 \pm 0.00$ & $91.0 \pm 0.04^{\mathrm{a}}$ & $0.32 \pm 0.07$ & $107.2 \pm 0.76$ & $0.14 \pm 0.03$ \\
\hline $\mathrm{MeHg} 2 \mu \mathrm{M}$ & $58.2 \pm 0.26^{\mathrm{a}}$ & $0.27 \pm 0.01$ & $44.9 \pm 0.17^{\mathrm{a}}$ & $0.40 \pm 0.09^{\mathrm{a}}$ & $89.2 \pm 1.43$ & $0.18 \pm 0.02$ \\
\hline $\mathrm{MeHg} 5 \mu \mathrm{M}$ & $40.1 \pm 0.74^{\mathrm{a}}$ & $0.39 \pm 0.06^{\mathrm{a}}$ & $34.6 \pm 0.27^{\mathrm{a}}$ & $0.43 \pm 0.00^{\mathrm{a}}$ & $29.4 \pm 0.44^{\mathrm{a}}$ & $0.50 \pm 0.08^{\mathrm{a}}$ \\
\hline $\mathrm{HgCl}_{2} 1 \mu \mathrm{M}$ & $85.0 \pm 0.31^{\mathrm{a}}$ & $0.19 \pm 0.01$ & $104.0 \pm 0.99$ & $0.17 \pm 0.01$ & $122.3 \pm 0.52^{\mathrm{a}}$ & $0.12 \pm 0.04$ \\
\hline $\mathrm{HgCl}_{2} 2 \mu \mathrm{M}$ & $88.3 \pm 0.09^{\mathrm{a}}$ & $0.18 \pm 0.02$ & $107.6 \pm 0.88$ & $0.18 \pm 0.07$ & $127.1 \pm 1.94$ & $0.12 \pm 0.01^{\mathrm{a}}$ \\
\hline $\mathrm{HgCl}_{2} 5 \mu \mathrm{M}$ & $89.2 \pm 0.91$ & $0.19 \pm 0.03$ & $116.1 \pm 0.23^{\mathrm{a}}$ & $0.18 \pm 0.03$ & $113.1 \pm 2.00$ & $0.17 \pm 0.00$ \\
\hline
\end{tabular}

${ }^{\mathrm{a} P}<0.05$, mercury-exposed cells vs. matched caffeine + mercury-exposed cells. MeHg, methyl mecury; Q:[(NOx/Cc)/(MTT/Cc)], oxidative stress coefficient; MTT, mitochondrial metabolic activity/cell viability.

Only $5 \mu \mathrm{M}$ MeHg led to a significantly higher oxidative stress intensity score and lower cell viability when compared with the controls in L-glutamine-free medium $(\mathrm{P}<0.05)$ at the first 24-h incubation period (Table I). However, at the end of the 48-h incubation period in glutamine-free medium, caffeine supplementation generated more marked oxidative stress and caused a significant decrease in cell viability, particularly in the $5 \mu \mathrm{M}$ MeHg-exposed SH-SY5Y cells (Table II). Moreover, in glutamine-free medium, caffeine supplementation enhanced mercury-induced oxidative stress by approximately $10-28 \%$ at the end of 48-h incubation period (Tables I and II). Following the addition of L-glutamine to the medium, $5 \mu \mathrm{M} \mathrm{MeHg}$ increased oxidative stress by $88.6 \%$ and decreased the total mitochondrial metabolic activity/cell viability by $48.7 \%$ at the first $24-\mathrm{h}$ in comparison to glutamine-free medium $(\mathrm{P}<0.05$; Table III), whereas the oxidative stress intensity score increased by $118 \%$, cell viability decreased by $26 \%$ in the $5 \mu \mathrm{M}$ MeHg-exposed SH-SY5Y cells after 48 -h of incubation in glutaminecontaining medium when compared to the cells cultued in glutamine-free medium (Table IV). In the glutamine-containing medium, exposure to $\mathrm{HgCl}_{2}$ resulted in a smaller increase in oxidative stress compared to exposure to $\mathrm{MeHg}$. Cell viability was higher when the cells were exposed to $\mathrm{HgCl}_{2}$ compared to $\mathrm{MeHg}$ (Tables III and IV). These results indicated that $\mathrm{MeHg}$ was more toxic than $\mathrm{HgCl}_{2}$ to the $\mathrm{SH}-\mathrm{SY} 5 \mathrm{Y}$ cells.

Of note, the addition of L-glutamine to the incubation medium increased oxidative stress by 133 and $118 \%$ in the cells exposed to 2 and $5 \mu \mathrm{M} \mathrm{MeHg}$, respectively, at the end of 48-h incubation period (Table IV). Furthermore, in the presence of L-glutamine, caffeine supplementation to $5 \mu \mathrm{M} \mathrm{MeHg}$-containing medium decreased the oxidative stress scores by 69 and $68 \%$ for 10 and $20 \mu \mathrm{M}$ caffeine, respectively. At the $48 \mathrm{~h}$, the addition of $10 \mu \mathrm{M}$ caffeine to the culture medium containing L-glutamine augmented cell viability by $93 \%$, while $20 \mu \mathrm{M}$ caffeine increased viability by $142 \%$, in comparison to the SH-SY5Y cells exposed only to $5 \mu \mathrm{M} \mathrm{MeHg}$. Moreover, incubation with 10 or $20 \mu \mathrm{M}$ caffeine attenuated $\mathrm{MeHg}$-induced toxicity in the presence of L-glutamine $(\mathrm{P}<0.05)$ (Table IV). Overall, caffeine ameliorated the cytotoxic effects of mercury at all concentrations. In these cases, following exposure to mercury, alterations in mitochondrial metabolic activity/cell viability inversely 
Table III. Oxidative stress intensity coefficient and total mitochondrial metabolic activity/viability of $\mathrm{MeHg}^{-}$and $\mathrm{HgCl}$-exposed SH-SY5Y human neuroblastoma cells at the end of the first 24-h incubation period with or without caffeine in glutamine-containing medium.

\begin{tabular}{|c|c|c|c|c|c|c|}
\hline & \multicolumn{2}{|c|}{ Without caffeine } & \multicolumn{2}{|c|}{$10 \mu \mathrm{M}$ caffeine } & \multicolumn{2}{|c|}{$20 \mu \mathrm{M}$ caffeine } \\
\hline & $\operatorname{MTT}(\%)$ & $\mathrm{Q}(\mu \mathrm{M} / \%)$ & MTT (\%) & $\mathrm{Q}(\mu \mathrm{M} / \%)$ & MTT (\%) & $\mathrm{Q}(\mu \mathrm{M} / \%)$ \\
\hline Control & $99.5 \pm 0.33$ & $0.19 \pm 0.07$ & $102.40 \pm 1.12$ & $0.21 \pm 0.07$ & $101.1 \pm 0.33$ & $0.18 \pm 0.03$ \\
\hline $\mathrm{MeHg} 1 \mu \mathrm{M}$ & $82.2 \pm 0.74^{\mathrm{a}}$ & $0.27 \pm 0.02^{\mathrm{a}}$ & $103.20 \pm 0.57$ & $0.24 \pm 0.02^{\mathrm{a}}$ & $84.80 \pm 0.67^{\mathrm{a}}$ & $0.24 \pm 0.05^{\mathrm{a}}$ \\
\hline $\mathrm{MeHg} 2 \mu \mathrm{M}$ & $73.79 \pm 0.63^{a}$ & $0.36 \pm 0.03^{a}$ & $94.50 \pm 0.38$ & $0.21 \pm 0.03$ & $84.70 \pm 1.00$ & $0.20 \pm 0.05$ \\
\hline $\mathrm{MeHg} 5 \mu \mathrm{M}$ & $28.7 \pm 0.56^{\mathrm{a}}$ & $0.66 \pm 0.02^{\mathrm{a}}$ & $67.30 \pm 0.54^{\mathrm{a}}$ & $0.28 \pm 0.01^{\mathrm{a}}$ & $73.1 \pm 0.25^{\mathrm{a}}$ & $0.26 \pm 0.04^{\mathrm{a}}$ \\
\hline $\mathrm{HgCl}_{2} 1 \mu \mathrm{M}$ & $91.32 \pm 0.17^{\mathrm{a}}$ & $0.17 \pm 0.05^{\mathrm{a}}$ & $102.5 \pm 1.27$ & $0.16 \pm 0.04$ & $103.5 \pm 2.59$ & $0.22 \pm 0.04$ \\
\hline $\mathrm{HgCl}_{2} 2 \mu \mathrm{M}$ & $80.81 \pm 0.37^{\mathrm{a}}$ & $0.36 \pm 0.07^{\mathrm{a}}$ & $92.7 \pm 1.52$ & $0.25 \pm 0.07$ & $113.8 \pm 1.02$ & $0.23 \pm 0.02$ \\
\hline $\mathrm{HgCl}_{2} 5 \mu \mathrm{M}$ & $73.65 \pm 0.02^{\mathrm{a}}$ & $0.36 \pm 0.04^{\mathrm{a}}$ & $105.9 \pm 0.55$ & $0.24 \pm 0.04^{\mathrm{a}}$ & $105.2 \pm 0.35$ & $0.27 \pm 0.01^{\mathrm{a}}$ \\
\hline
\end{tabular}

${ }^{\mathrm{a}} \mathrm{P}<0.05$, mercury-exposed cells vs. matched caffeine + mercury-exposed cells. MeHg, methyl mecury; Q:[(NOx/Cc)/(MTT/Cc)], oxidative stress coefficient; MTT, mitochondrial metabolic activity/cell viability.

Table IV. Oxidative stress intensity coefficient and total mitochondrial metabolic activity/viability of $\mathrm{MeHg}^{-}$and $\mathrm{HgCl}{ }_{2}$-exposed SH-SY5Y human neuroblastoma cells at the end of the second 24-h incubation period with or without caffeine in glutaminecontaining medium.

\begin{tabular}{|c|c|c|c|c|c|c|}
\hline & \multicolumn{2}{|c|}{ Without caffeine } & \multicolumn{2}{|c|}{$10 \mu \mathrm{M}$ caffeine } & \multicolumn{2}{|c|}{$20 \mu \mathrm{M}$ caffeine } \\
\hline & $\operatorname{MTT}(\%)$ & $\mathrm{Q}(\mu \mathrm{M} / \%)$ & MTT (\%) & $\mathrm{Q}(\mu \mathrm{M} / \%)$ & MTT (\%) & $\mathrm{Q}(\mu \mathrm{M} / \%)$ \\
\hline Control & $100.0 \pm 0.38$ & $0.36 \pm 0.15$ & $93.8 \pm 1.27$ & $0.24 \pm 0.05$ & $108.5 \pm 0.20^{\mathrm{a}}$ & $0.15 \pm 0.02^{\mathrm{a}}$ \\
\hline $\mathrm{MeHg} 1 \mu \mathrm{M}$ & $82.42 \pm 0.79^{a}$ & $0.33 \pm 0.02$ & $111.7 \pm 1.26$ & $0.24 \pm 0.04$ & $104.5 \pm 0.87$ & $0.22 \pm 0.01$ \\
\hline $\mathrm{MeHg} 2 \mu \mathrm{M}$ & $53.09 \pm 0.04^{\mathrm{a}}$ & $0.63 \pm 0.03^{\mathrm{a}}$ & $79.5 \pm 0.23^{\mathrm{a}}$ & $0.32 \pm 0.05$ & $74.1 \pm 1.50^{\mathrm{a}}$ & $0.18 \pm 0.02$ \\
\hline $\mathrm{MeHg} 5 \mu \mathrm{M}$ & $29.60 \pm 1.74^{\mathrm{a}}$ & $0.85 \pm 0.16^{\mathrm{a}}$ & $57.0 \pm 1.57^{\mathrm{a}}$ & $0.26 \pm 0.02^{\mathrm{a}}$ & $71.7 \pm 0.02^{\mathrm{a}}$ & $0.27 \pm 0.21^{\mathrm{a}}$ \\
\hline $\mathrm{HgCl}_{2} 1 \mu \mathrm{M}$ & $89.16 \pm 0.13^{\mathrm{a}}$ & $0.25 \pm 0.11^{\mathrm{a}}$ & $103.8 \pm 1.27$ & $0.15 \pm 0.03^{\mathrm{a}}$ & $117.1 \pm 0.09^{a}$ & $0.14 \pm 0.02^{\mathrm{a}}$ \\
\hline $\mathrm{HgCl}_{2} 2 \mu \mathrm{M}$ & $76.44 \pm 0.14$ & $0.29 \pm 0.14$ & $111.8 \pm 0.94$ & $0.16 \pm 0.03^{\mathrm{a}}$ & $107.0 \pm 0.18^{\mathrm{a}}$ & $0.23 \pm 0.06$ \\
\hline $\mathrm{HgCl}_{2} 5 \mu \mathrm{M}$ & $61.12 \pm 0.40^{\mathrm{a}}$ & $0.35 \pm 0.11$ & $98.3 \pm 0.82$ & $0.18 \pm 0.00$ & $86.8 \pm 1.09$ & $0.28 \pm 0.09$ \\
\hline
\end{tabular}

${ }^{\mathrm{a}} \mathrm{P}<0.05$, mercury-exposed cells vs. matched caffeine + mercury-exposed cells. MeHg, methyl mecury; Q:[(NOx/Cc)/(MTT/Cc)], oxidative stress coefficient; MTT, mitochondrial metabolic activity/cell viability.

correlated with oxidative stress intensity scores. Furthermore, the increase in the NOx generation-related oxidative stress and the decrease in cell viability were also inversely proportional in a dose-dependent manner, particularly in $\mathrm{MeHg}$-exposed cells in the presence of L-glutamine.

On the other hand, the addition of caffeine to the glutamine-free medium had no significant effect on $\mathrm{HgCl}_{2}$-related oxidative stress and mitochondrial metabolic activity/cell viability. By contrast, caffeine supplementation to the glutamine-containing medium significantly attenuated $\mathrm{MeHg}$ - and $\mathrm{HgCl}_{2}$-related toxicity at the matched doses and for all concentrations during the first and second 24-h incubation periods. These results were interpreted as the consumption of antioxidant capacity due to mercury-induced toxicity. Thus, the most striking toxicity was observed with $5 \mu \mathrm{M} \mathrm{MeHg}$. It should be noted that a significant amount of extracellular glutathione is directly derived from glutamine. Culture in glutamine-free medium reduces cell proliferation and viability and abolishes glutathione excretion (34).
The effects of L-glutamine on IFN- $\gamma$ - and caffeine-supplemented medium on the total mitochondrial metabolic activity and oxidative stress in mercury-exposed SH-SY5Y cells are shown in Tables V-VIII. Stimulation of the SH-SY5Y cells with IFN- $\gamma$ in glutamine-free medium irregularly affected the caffeine-controlled mercury-induced toxicity when compared to cells exposed to mercury only. Moreover, $10 \mu \mathrm{M}$ caffeine augmented $5 \mu \mathrm{M}$ MeHg-induced oxidative stress by $125.6 \%$ in glutamine-free medium, when the medium was supplemented with IFN- $\gamma$ at the end of the $48-h$ incubation period. When glutamine was added to the IFN- $\gamma$-containing medium, the SH-SY5Y cells were $42 \%$ less protected by $10 \mu \mathrm{M}$ caffeine in comparison to only glutamine-containing medium. In glutamine-containing medium, $10 \mu \mathrm{M}$ caffeine decreased $5 \mu \mathrm{M} \mathrm{MeHg}$-induced oxidative stress by 58 and $69 \%$ at the first 24-h and second 24-h incubation periods, respectively. However, under co-stimulation with glutamine and IFN- $\gamma$, $10 \mu \mathrm{M}$ caffeine reduced $5 \mu \mathrm{M}$ MeHg-induced oxidative stress in the SH-SY5Y cells by 44 and $56 \%$ at the first $24-\mathrm{h}$ and 
Table V. Oxidative stress intensity coefficient and total mitochondrial metabolic activity/viability of $\mathrm{MeHg}^{-}$and $\mathrm{HgCl}{ }_{2}$-exposed SH-SY5Y human neuroblastoma cells at the end of the first 24-h incubation period with or without caffeine in glutamine-free and IFN- $\gamma$-containing medium.

\begin{tabular}{|c|c|c|c|c|c|c|}
\hline & \multicolumn{2}{|c|}{ Without caffeine } & \multicolumn{2}{|c|}{$10 \mu \mathrm{M}$ caffeine + IFN $-\gamma$} & \multicolumn{2}{|c|}{$20 \mu \mathrm{M}$ caffeine + IFN $-\gamma$} \\
\hline & $\operatorname{MTT}(\%)$ & $\mathrm{Q}(\mu \mathrm{M} / \%)$ & MTT (\%) & $\mathrm{Q}(\mu \mathrm{M} / \%)$ & MTT (\%) & $\mathrm{Q}(\mu \mathrm{M} / \%)$ \\
\hline Control & $99.4 \pm 0.16$ & $0.18 \pm 0.13$ & $79.6 \pm 1.02^{\mathrm{a}}$ & $0.23 \pm 0.05^{\mathrm{a}}$ & $82.9 \pm 0.87$ & $0.25 \pm 0.05$ \\
\hline $\mathrm{MeHg} 1 \mu \mathrm{M}$ & $91.9 \pm 0.18^{\mathrm{a}}$ & $0.23 \pm 0.07$ & $98.6 \pm 1.68$ & $0.27 \pm 0.03$ & $109.2 \pm 0.74$ & $0.19 \pm 0.09^{\mathrm{a}}$ \\
\hline $\mathrm{MeHg} 2 \mu \mathrm{M}$ & $94.4 \pm 0.51$ & $0.24 \pm 0.02^{\mathrm{a}}$ & $102.6 \pm 0.41$ & $0.19 \pm 0.00^{\mathrm{a}}$ & $100.4 \pm 0.54$ & $0.19 \pm 0.08^{\mathrm{a}}$ \\
\hline $\mathrm{MeHg} 5 \mu \mathrm{M}$ & $56.0 \pm 1.02^{\mathrm{a}}$ & $0.35 \pm 0.04^{\mathrm{a}}$ & $65.5 \pm 0.51^{\mathrm{a}}$ & $0.28 \pm 0.02$ & $60.1 \pm 0.23^{a}$ & $0.33 \pm 0.07^{\mathrm{a}}$ \\
\hline $\mathrm{HgCl}_{2} 1 \mu \mathrm{M}$ & $104.3 \pm 0.47$ & $0.18 \pm 0.05$ & $96.2 \pm 1.22$ & $0.19 \pm 0.01^{\mathrm{a}}$ & $96.6 \pm 1.80$ & $0.18 \pm 0.00^{\mathrm{a}}$ \\
\hline $\mathrm{HgCl}_{2} 2 \mu \mathrm{M}$ & $104.8 \pm 0.01^{\mathrm{a}}$ & $0.23 \pm 0.06$ & $97.3 \pm 0.93$ & $0.19 \pm 0.04^{\mathrm{a}}$ & $93.4 \pm 0.87$ & $0.21 \pm 0.00^{\mathrm{a}}$ \\
\hline $\mathrm{HgCl}_{2} 5 \mu \mathrm{M}$ & $104.4 \pm 0.86$ & $0.19 \pm 0.04$ & $101.8 \pm 0.79$ & $0.17 \pm 0.02^{\mathrm{a}}$ & $91.9 \pm 0.35^{a}$ & $0.23 \pm 0.03^{\mathrm{a}}$ \\
\hline
\end{tabular}

${ }^{a} \mathrm{P}<0.05$, mercury-exposed cells vs. matched caffeine + mercury-exposed cells. MeHg, methyl mecury; Q:[(NOx/Cc)/(MTT/Cc)], oxidative stress coefficient; MTT, mitochondrial metabolic activity/cell viability; IFN- $\gamma$, interferon- $\gamma$.

Table VI. Oxidative stress intensity coefficient and total mitochondrial metabolic activity/viability of $\mathrm{MeHg}$ and $\mathrm{HgCl} \mathrm{H}_{2}$-exposed SH-SY5Y human neuroblastoma cells at the end of the second 24-h incubation period with or without caffeine in glutamine-free and IFN- $\gamma$-containing medium.

\begin{tabular}{|c|c|c|c|c|c|c|}
\hline & \multicolumn{2}{|c|}{ Without caffeine } & \multicolumn{2}{|c|}{$10 \mu \mathrm{M}$ caffeine + IFN- $\gamma$} & \multicolumn{2}{|c|}{$20 \mu \mathrm{M}$ caffeine + IFN- $\gamma$} \\
\hline & $\operatorname{MTT}(\%)$ & $\mathrm{Q}(\mu \mathrm{M} / \%)$ & $\operatorname{MTT}(\%)$ & $\mathrm{Q}(\mu \mathrm{M} / \%)$ & $\operatorname{MTT}(\%)$ & $\mathrm{Q}(\mu \mathrm{M} / \%)$ \\
\hline Control & $99.8 \pm 0.22$ & $0.23 \pm 0.16$ & $92.6 \pm 1.51$ & $0.30 \pm 0.03$ & $121.0 \pm 1.36^{\mathrm{a}}$ & $0.22 \pm 0.02^{\mathrm{a}}$ \\
\hline $\mathrm{MeHg} 1 \mu \mathrm{M}$ & $100.2 \pm 0.35$ & $0.19 \pm 0.00$ & $79.7 \pm 0.28^{a}$ & $0.40 \pm 0.02^{\mathrm{a}}$ & $88.4 \pm 0.45^{\mathrm{a}}$ & $0.21 \pm 0.02^{\mathrm{a}}$ \\
\hline $\mathrm{MeHg} 2 \mu \mathrm{M}$ & $58.2 \pm 0.26^{\mathrm{a}}$ & $0.27 \pm 0.01$ & $63.8 \pm 0.70^{\mathrm{a}}$ & $0.33 \pm 0.02$ & $83.2 \pm 0.52^{\mathrm{a}}$ & $0.27 \pm 0.09$ \\
\hline $\mathrm{MeHg} 5 \mu \mathrm{M}$ & $40.1 \pm 0.74^{\mathrm{a}}$ & $0.39 \pm 0.06^{\mathrm{a}}$ & $28.9 \pm 0.49^{\mathrm{a}}$ & $0.97 \pm 0.11^{\mathrm{a}}$ & $36.5 \pm 0.56^{a}$ & $0.46 \pm 0.09^{\mathrm{a}}$ \\
\hline $\mathrm{HgCl}_{2} 1 \mu \mathrm{M}$ & $85.0 \pm 0.31^{\mathrm{a}}$ & $0.19 \pm 0.01$ & $93.2 \pm 1.79$ & $0.18 \pm 0.01^{\mathrm{a}}$ & $93.4 \pm 0.78$ & $0.19 \pm 0.03^{\mathrm{a}}$ \\
\hline $\mathrm{HgCl}_{2} 2 \mu \mathrm{M}$ & $88.3 \pm 0.09^{\mathrm{a}}$ & $0.18 \pm 0.02$ & $94.4 \pm 0.77$ & $0.19 \pm 0.07^{\mathrm{a}}$ & $95.4 \pm 0.89$ & $0.19 \pm 0.00^{\mathrm{a}}$ \\
\hline $\mathrm{HgCl}_{2} 5 \mu \mathrm{M}$ & $89.2 \pm 0.91$ & $0.19 \pm 0.03$ & $94.4 \pm 0.93$ & $0.21 \pm 0.12^{\mathrm{a}}$ & $85.4 \pm 0.11^{\mathrm{a}}$ & $0.25 \pm 0.02^{\mathrm{a}}$ \\
\hline
\end{tabular}

${ }^{\mathrm{a}} \mathrm{P}<0.05$, mercury-exposed cells vs. matched caffeine + mercury-exposed cells. MeHg, methyl mecury; Q:[(NOx/Cc)/(MTT/Cc)], oxidative stress coefficient; MTT, mitochondrial metabolic activity/cell viability; IFN- $\gamma$, interferon- $\gamma$.

second 24-h incubation periods, respectively. This suggests that the IFN- $\gamma$-stimulated SH-SY5Y cells in glutamine-free medium almost remained unresponsive to mercury-induced toxicity despite caffeine supplementation (Tables V and VI). Eventually, at the second $24 \mathrm{~h}$ incubation period, the addition of IFN- $\gamma$ and caffeine to glutamine-free medium significantly enhanced the toxicity of $\mathrm{MeHg}(\mathrm{p}<0.05)$.

In the L-glutamine-containing medium, $\mathrm{MeHg}$ treatment decreased the average cell viability of IFN- $\gamma$-stimulated neuronal cells following caffeine supplementation in comparison to the controls (Tables VII and VIII). Following the stimulation of neuronal cells with IFN- $\gamma$, caffeine supplementation provided a partial improvement in $\mathrm{MeHg}$ toxicity in comparison to the unstimulated counterparts. When taking into account the mitochondrial metabolic activities and oxidative stress scores, IFN- $\gamma$ and caffeine were more effective against $\mathrm{HgCl}_{2}$-induced toxicity than $\mathrm{MeHg}$. On the one hand, L-glutamine increased mercury-induced toxicity, but on the other hand, it was required for improving the effects of caffeine against mercury-induced toxicity in IFN- $\gamma$-stimulated SH-SY5Y cells.
Of note, the most effective concentration was $20 \mu \mathrm{M}$ caffeine in recovering cell viability and oxidative stress intensity of the mercury-exposed cells, which were pre-treated with IFN- $\gamma$ in L-glutamine-containing medium $(\mathrm{P}<0.05)$. The addition of IFN- $\gamma$ to the glutamine-containing medium aggravated average cell viability of the 24 - plus 48 -h incubation periods by 15 and $22 \%$ in the 10 and $20 \mu \mathrm{M}$ caffeine-stimulated cells, respectively. These findings were in accordance with the increase in the oxidative stress intensity score with the IFN- $\gamma$ stimulation of $\mathrm{MeHg}$-exposed cells. Similarly, when the mean values of the 24- and 48-h incubation periods were considered, the elevation of Q was 37 and $31 \%$ in the 10 and $20 \mu \mathrm{M}$ caffeine supplemented medium, respectively. The IFN- $\gamma$ stimulation of mercury-exposed SH-SY5Y cells in the glutamine-containing medium reduced the protective effects of caffeine.

\section{Discussion}

Glutamine is the primary precursor for the biosynthesis of the neurotransmitters glutamate and $\gamma$-aminobutyric acid. It 
Table VII. Oxidative stress intensity coefficient and total mitochondrial metabolic activity/viability of $\mathrm{MeHg}$ and $\mathrm{HgCl}{ }_{2}$-exposed SH-SY5Y human neuroblastoma cells at the end of the first 24-h incubation period with or without caffeine in glutamine- and IFN- $\gamma$-containing medium.

\begin{tabular}{|c|c|c|c|c|c|c|}
\hline & \multicolumn{2}{|c|}{ Without caffeine } & \multicolumn{2}{|c|}{$10 \mu \mathrm{M}$ caffeine $+\mathrm{IFN}-\gamma$} & \multicolumn{2}{|c|}{$20 \mu \mathrm{M}$ caffeine + IFN $-\gamma$} \\
\hline & $\operatorname{MTT}(\%)$ & $\mathrm{Q}(\mu \mathrm{M} / \%)$ & MTT (\%) & $\mathrm{Q}(\mu \mathrm{M} / \%)$ & $\operatorname{MTT}(\%)$ & $\mathrm{Q}(\mu \mathrm{M} / \%)$ \\
\hline Control & $99.5 \pm 0.33$ & $0.19 \pm 0.07$ & $92.1 \pm 1.91$ & $0.17 \pm 0.01$ & $107.4 \pm 1.44$ & $0.23 \pm 0.06$ \\
\hline $\mathrm{MeHg} 1 \mu \mathrm{M}$ & $82.2 \pm 0.74^{\mathrm{a}}$ & $0.27 \pm 0.02^{\mathrm{a}}$ & $82.60 \pm 1.21^{\mathrm{a}}$ & $0.32 \pm 0.06$ & $104.9 \pm 0.37$ & $0.20 \pm 0.16$ \\
\hline $\mathrm{MeHg} 2 \mu \mathrm{M}$ & $73.79 \pm 0.63^{\mathrm{a}}$ & $0.36 \pm 0.03^{\mathrm{a}}$ & $87.00 \pm 0.15^{\mathrm{a}}$ & $0.20 \pm 0.07^{\mathrm{a}}$ & $89.8 \pm 0.32$ & $0.20 \pm 0.02^{\mathrm{a}}$ \\
\hline $\mathrm{MeHg} 5 \mu \mathrm{M}$ & $28.7 \pm 0.56^{\mathrm{a}}$ & $0.66 \pm 0.02^{\mathrm{a}}$ & $59.50 \pm 0.72^{\mathrm{a}}$ & $0.37 \pm 0.03^{\mathrm{a}}$ & $54.3 \pm 1.03^{\mathrm{a}}$ & $0.32 \pm 0.04^{\mathrm{a}}$ \\
\hline $\mathrm{HgCl}_{2} 1 \mu \mathrm{M}$ & $91.32 \pm 0.17^{\mathrm{a}}$ & $0.17 \pm 0.05^{\mathrm{a}}$ & $99.1 \pm 0.81$ & $0.20 \pm 0.01^{\mathrm{a}}$ & $129.6 \pm 2.37$ & $0.13 \pm 0.00^{\mathrm{a}}$ \\
\hline $\mathrm{HgCl}_{2} 2 \mu \mathrm{M}$ & $80.81 \pm 0.37^{\mathrm{a}}$ & $0.36 \pm 0.07^{\mathrm{a}}$ & $104.0 \pm 0.27$ & $0.22 \pm 0.05^{\mathrm{a}}$ & $99.5 \pm 0.48$ & $0.23 \pm 0.02^{\mathrm{a}}$ \\
\hline $\mathrm{HgCl}_{2} 5 \mu \mathrm{M}$ & $73.65 \pm 0.02^{\mathrm{a}}$ & $0.36 \pm 0.04^{\mathrm{a}}$ & $103.4 \pm 0.85$ & $0.18 \pm 0.02$ & $95.3 \pm 0.17^{\mathrm{a}}$ & $0.19 \pm 0.03^{\mathrm{a}}$ \\
\hline
\end{tabular}

${ }^{\text {aP }}<0.05$, mercury-exposed cells vs. matched caffeine + mercury-exposed cells. MeHg, methyl mecury; Q:[(NOx/Cc)/(MTT/Cc)], oxidative stress coefficient; MTT, mitochondrial metabolic activity/cell viability; IFN- $\gamma$, interferon- $\gamma$.

Table VIII. Oxidative stress intensity coefficient and total mitochondrial metabolic activity/viability of $\mathrm{MeHg}_{-}$and $\mathrm{HgCl}{ }_{2}-\mathrm{exposed}$ SH-SY5Y human neuroblastoma cells at the end of the second 24-h incubation period with or without caffeine in glutamine- and IFN- $\gamma$-containing medium.

\begin{tabular}{|c|c|c|c|c|c|c|}
\hline & \multicolumn{2}{|c|}{ Without caffeine } & \multicolumn{2}{|c|}{$10 \mu \mathrm{M}$ caffeine $+\mathrm{IFN}-\gamma$} & \multicolumn{2}{|c|}{$20 \mu \mathrm{M}$ caffeine + IFN $-\gamma$} \\
\hline & $\operatorname{MTT}(\%)$ & $\mathrm{Q}(\mu \mathrm{M} / \%)$ & MTT (\%) & $\mathrm{Q}(\mu \mathrm{M} / \%)$ & $\operatorname{MTT}(\%)$ & $\mathrm{Q}(\mu \mathrm{M} / \%)$ \\
\hline Control & $100.0 \pm 0.38$ & $0.36 \pm 0.15$ & $102.4 \pm 0.52$ & $0.24 \pm 0.14$ & $98.7 \pm 1.82$ & $0.19 \pm 0.00^{\mathrm{a}}$ \\
\hline $\mathrm{MeHg} 1 \mu \mathrm{M}$ & $82.42 \pm 0.79^{a}$ & $0.33 \pm 0.02$ & $98.5 \pm 0.32$ & $0.34 \pm 0.16$ & $114.0 \pm 1.34$ & $0.15 \pm 0.00^{\mathrm{a}}$ \\
\hline $\mathrm{MeHg} 2 \mu \mathrm{M}$ & $53.09 \pm 0.04^{\mathrm{a}}$ & $0.63 \pm 0.03^{\mathrm{a}}$ & $107.1 \pm 0.67$ & $0.27 \pm 0.07$ & $108.3 \pm 1.07$ & $0.16 \pm 0.05$ \\
\hline $\mathrm{MeHg} 5 \mu \mathrm{M}$ & $29.60 \pm 1.74^{\mathrm{a}}$ & $0.85 \pm 0.16^{\mathrm{a}}$ & $46.7 \pm 0.50^{\mathrm{a}}$ & $0.37 \pm 0.02^{\mathrm{a}}$ & $58.8 \pm 0.73^{a}$ & $0.36 \pm 0.00^{\mathrm{a}}$ \\
\hline $\mathrm{HgCl}_{2} 1 \mu \mathrm{M}$ & $89.16 \pm 0.13^{\mathrm{a}}$ & $0.25 \pm 0.11^{\mathrm{a}}$ & $104.1 \pm 0.03^{\mathrm{a}}$ & $0.17 \pm 0.05^{\mathrm{a}}$ & $116.6 \pm 0.40$ & $0.20 \pm 0.03^{\mathrm{a}}$ \\
\hline $\mathrm{HgCl}_{2} 2 \mu \mathrm{M}$ & $76.44 \pm 0.14$ & $0.29 \pm 0.14$ & $92.2 \pm 2.49$ & $0.27 \pm 0.05$ & $101.0 \pm 0.10$ & $0.25 \pm 0.05^{\mathrm{a}}$ \\
\hline $\mathrm{HgCl}_{2} 5 \mu \mathrm{M}$ & $61.12 \pm 0.40^{\mathrm{a}}$ & $0.35 \pm 0.11$ & $91.0 \pm 1.20$ & $0.39 \pm 0.02$ & $85.2 \pm 1.28$ & $0.23 \pm 0.08^{\mathrm{a}}$ \\
\hline
\end{tabular}

${ }^{a} \mathrm{P}<0.05$, mercury-exposed cells vs. matched caffeine + mercury-exposed cells. MeHg, methyl mecury; Q:[(NOx/Cc)/(MTT/Cc)], oxidative stress coefficient; MTT, mitochondrial metabolic activity/cell viability; IFN- $\gamma$, interferon- $\gamma$.

is proposed that in vivo glutamine is synthesized and released by astrocytes, and is then transported into the neuron for subsequent conversion to neurotransmitters (35). The uptake of glutamine by neurons is an integral step in the glutamate-glutamine cycle, and a major pathway for the replenishment of neuronal glutamate (36). Besides, glutamatergic neurons exhibit highly efficient transport systems to accumulate L-glutamine, one of the major precursors of glutamate (37). Glutamine re-appears in neurons before conversion back to glutamate by glutaminase $(38,39)$. In this respect, without glutamine influx, SH-SY5Y cells cannot produce glutamate in glutamine-free medium (40). The neuroblastoma cell line, SH-SY5Y, expresses a novel form of phosphate activated glutaminase (PAG) which deamidates glutamine to glutamate and ammonia at high rates (41). Glutamate dyshomeostasis and oxidative stress have been identified as two critical mechanisms mediating $\mathrm{MeHg}$-induced neurotoxicity. Glutamate/aspartate transporter (GLAST) and glutamate transporter-1 (GLT-1) appear to be inhibited by MeHg exposure (6) (Fig. 1).
In neurons, mitochondrial metabolism of exogenous glutamine is mainly responsible for the net synthesis of glutamate, which is a neurotransmitter, but it is also necessary for the synthesis of glutathione, the main endogenous antioxidant (42). Thereby mitochondrial metabolic activity is very important with respect to glutamatergic neurotransmission and cell antioxidant capacity. The increased activity of GSH/glutamate-cysteine ligase (GCL) in the cytoplasm also leads to the concurrent elevation of GSH in the mitochondrial compartment (Fig. 1). Kaur et al demonstrated that treatment with $5 \mu \mathrm{M} \mathrm{MeHg}$ for $30 \mathrm{~min}$ led to a significant increase in ROS generation and reduction in GSH content (43). In a previous study, SH-SY5Y cells treated for $24 \mathrm{~h}$ with $\mathrm{MeHg}$ exhibited a significant reduction in glutathione peroxidase activity in the brain. There was a concomitant significant decrease in cell viability and an increase in apoptosis (44). In this context, $\mathrm{MeHg}$ may react readily with $\mathrm{GSH}$, leading to the formation of a $\mathrm{MeHg}-\mathrm{SG}$ adduct that is excreted into the extracellular space of SH-SY5Y human neuroblastoma cells (45). As an expected result, we found that 


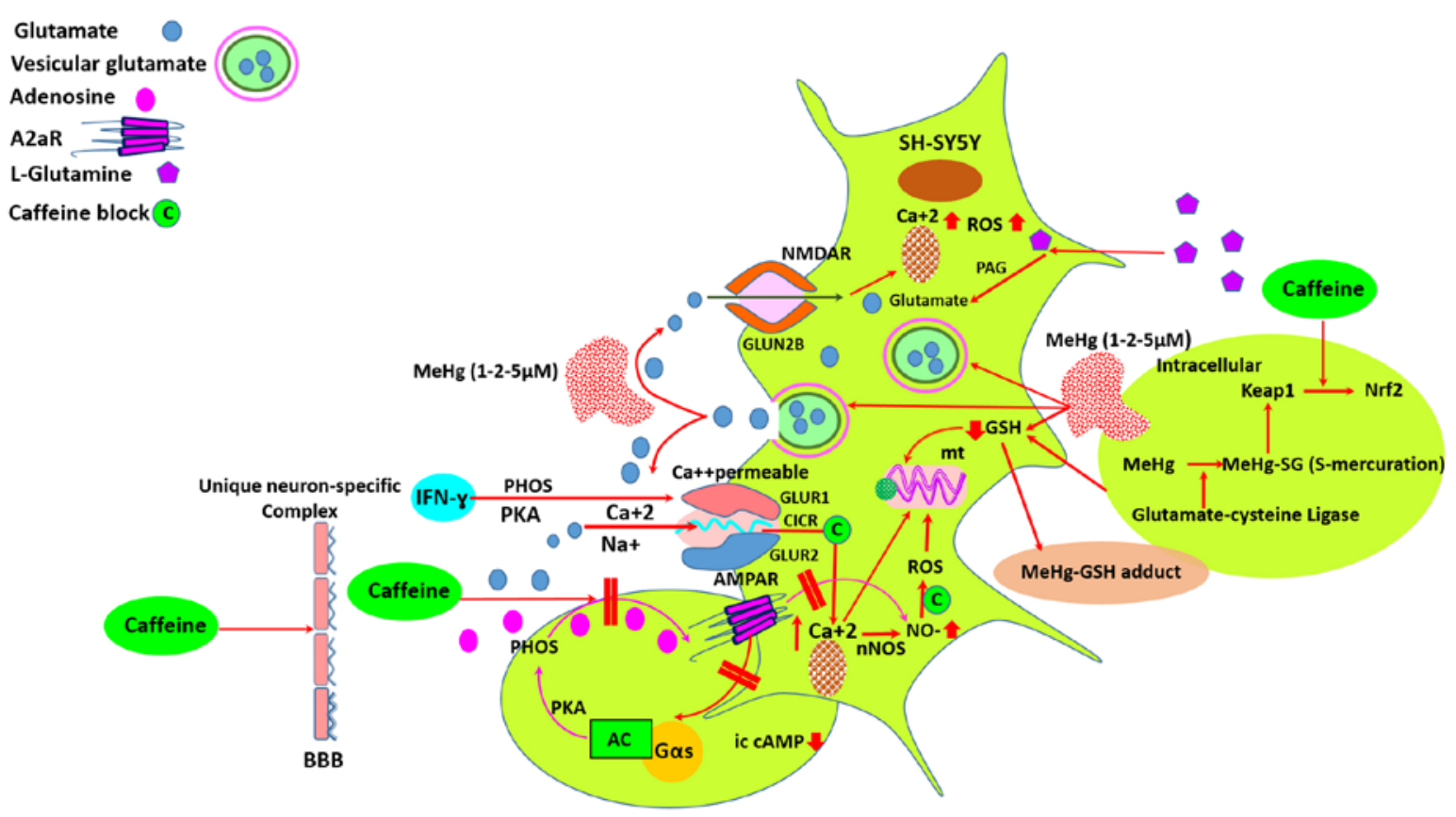

Figure 1. Mercury-induced neuronal death may occur via the glutamate-mediated excitotoxicity through NMDARs. Adenosine receptors blockade by caffeine equivalent doses of daily coffee consumption may reduce the vulnerability to mercury species-induced oxidative stress in L-glutamine contained medium. IFN- $\gamma$ sensitizes the mercury-exposed SH-SY5Y dopaminergic neurons via AMPA receptor complex, and may diminish the neuroprotective effect of caffeine in the presence of L-glutamine. MeHg, methyl mercury; PAG, phosphate activated glutaminase; GSH, reduced glutathione; NMDAR, N-methyl-D-aspartate receptor; AMPAR, $\alpha$-amino-3-hydroxy-5-methyl-4-isoxazolepropionic acid receptor (iontotropic glutamate receptor); IFN- $\gamma$, interferon- $\gamma$; mt, mitochondria; ROS, reactive oxygen species; nNOS, neuronal nitric oxide synthase; PKA, protein kinase A; A2aR, adenosine A2a receptor; PHOS, pphosphorylation of A2aR; AC, adenylyl cyclase; Gas, stimulatory G-protein subunit; ic cAMP, intracellular second messenger cyclic adenosine monophosphate (cAMP); BBB, blood-brain barrier; CICR, calcium-induced calcium release; Nrf2, nuclear factor (erythroid-derived 2)-like 2; Keap1, Kelch-like ECH-associated protein 1.

imercury-induced oxidative stress was not significantly affected in SH-SY5Y cells in glutamine-free medium, except, $5 \mu \mathrm{M}$ $\mathrm{MeHg}$ exposure, whereas the toxic effects of mercury were significantly enhanced in L-glutamine-containing medium, particularly during the second 24-h incubation period.

Coffee consumption significantly reduced mercury-related toxicity. Of note, caffeine acting through adenosine receptors plays a prominent role in modulating glutamatergic input to various neurons (Fig. 1). Similarly, glutamate acts on both ionotropic and metabotropic $\mathrm{G}$ protein-coupled receptors. Therefore, intense glutamatergic neurotransmission is known to induce adenosine release (46). On the other hand, caffeine blocks calcium-induced calcium release (CICR) triggered by calcium influx through calcium permeable AMPA receptors (47). In our study, the addition of glutamine to the incubation medium increased the oxidative stress intensity by $89-118 \%$ in the $5 \mu \mathrm{M}$ MeHg-exposed SH-SY5Y cells. Furthermore, caffeine supplementation to L-glutamine-containing incubation medium reversed the cytotoxicity of mercury compounds when compared with the caffeine-free controls. Caffeine-mediated effects may occur with at least two mechanisms: by directly blocking the glutamate activated channels or by reducing postsynaptic glutamate receptor density. In this respect, on the one hand caffeine decreases glutamatergic excitatory post-synaptic currents amplitude by direct postsynaptic block of glutamate-activated channels. On the other hand, caffeine directly blocks AMPA receptor-mediated calcium currents responsible for CICR (48). In daily life, caffeine concentration in blood reaches approximately 20-30 $\mu \mathrm{M}$ after ingestion of the equivalent of 2 cups of coffee (28). Thus, in our study, the maximum dose supplemented to the incubation medium was $20 \mu \mathrm{M}$. Indeed, the blood-brain barrier is readily permeable to caffeine, and thus the concentration in the brain is close to that in the blood (49). Caffeine inhibits glutamate receptors with an apparent $\mathrm{IC}_{50}$ value of approximately $10 \mathrm{mM}$. Therefore, ingested caffeine is unlikely to have any effect on ionotropic glutamate receptors. Instead, caffeine likely produces stimulatory effects in humans through its potent antagonism of the adenosine receptor (50). Caffeine-mediated glutamate receptor blockade may only occur under extreme conditions of toxicity (48).

Deletion of the A2A adenosine receptor reduces the vulnerability to $\mathrm{MeHg}$, consistent with the neuroprotective effects of adenosine A2A receptor inactivation. Thus, $\mathrm{MeHg}$ toxicity can be reduced by adenosine $\mathrm{A} 1$ and $\mathrm{A} 2 \mathrm{~A}$ receptor inactivation, either via their genetic deletion or by treatment with their antagonist caffeine (51). In this study, in glutamine-free medium, caffeine did not block the toxicity of $5 \mu \mathrm{M} \mathrm{MeHg}$. Thus, we observed a significant increase in the oxidative stress intensity score and a marked decrease in mitochondrial metabolic activity in the mercury-exposed SH-SY5Y cells. Substantially, MeHg disrupts glutamate metabolism and overexcites NMDA receptors of the neurons. At the same time, $\mathrm{MeHg}$ reduces non-enzymatic and enzymatic antioxidants, enhances neurocyte apoptosis, induces reactive oxygen species, and causes DNA peroxidative damage in the neurons (52). However, in our study, caffeine supplementation to glutamine-containing medium substantially ameliorated matched doses of $\mathrm{MeHg}$ - and $\mathrm{HgCl}_{2}$-related toxicity. Caffeineinhibited currents are activated by the direct application of glutamate to cortical neurons, confirming a post-synaptic site of action. This unexpected form of inhibition develops over tens of 
milliseconds and is independent of NMDA receptors, consistent with non-NMDA receptor block (48). Furthermore, on human neuronal SH-SY5Y cells, caffeine shows concentration-dependent non-enzymatic antioxidant potential, decreases the basal levels of free radical generation, and reduces both superoxide dismutase and catalase activities (53). In addition, chronic coffee or caffeine ingestion reduces the lipid peroxidation in membranes of brain cells and increases the concentration of reduced-glutathione (54). We found that in glutamine-free medium, caffeine supplementation was insufficient to control $5 \mu \mathrm{M} \mathrm{MeHg-induced} \mathrm{oxidative} \mathrm{stress.}$ However, in glutamine-containing medium, caffeine inhibited $\mathrm{MeHg}$-induced-oxidative stress by approximately 58 and $69 \%$ at the end of first and second incubation periods, respectively. These results confirmed that the antioxidant potential of caffeine was activated by glutamate, but was not mediated by NMDA receptor. In our study, we also demonstrated that equivalent doses of caffeine which were received during the daily coffee intake, substantially inhibited mercury-induced oxidative stress. However, NMDA receptor-mediated currents do not change in the presence of caffeine. Collectively, caffeine is a non-selective adenosine $\mathrm{A} 1$ and $\mathrm{A} 2 \mathrm{~A}$ receptor antagonist that attenuates dopaminergic neurotoxicity and neurodegeneration (55) (Fig. 1). It has been shown that pre-treatment with caffeine provides a partial neuro-protection against severe striatal degeneration in dopaminergic neurons and diminishes the extracellular glutamate in the brain (56).

Whether the effect of caffeine was mediated by a mechanism other than the NMDA receptor was examined by IFN- $\gamma$. IFN- $\gamma$ is a pro-inflammatory cytokine that plays a pivotal role in the pathology of diseases in the CNS (20). Titze-de-Almeida et al demonstrated that IFN- $\gamma$ sensitized SH-SY5Y cells to neurotoxin-induced injury, also causing an increase in ROS levels (57). Furthermore, IFN- $\gamma$ directly induces neuronal dysfunction and enhances glutamate neurotoxicity mediated by AMPA receptors, but not NMDA receptors (20). Thus, in our study, IFN- $\gamma$ in the pure SH-SY5Y cell culture worked synergistically with glutamate to promote neuronal excitotoxicity presumably through AMPA receptor complex in SH-SY5Y cells (Fig. 1). At the second 24-h incubation period, the addition of caffeine to IFN- $\gamma$-stimulated cells in glutamine-free medium significantly enhanced the toxicity of $5 \mu \mathrm{M} \mathrm{MeHg}$. This result is in accordance with the findings of Titze-de-Almeida et al (57) and Vikman et al (58). Thus, Vikman et al indicated that when the neurons were treated with IFN- $\gamma$, neurophysiological alterations could be observed $48 \mathrm{~h}$ following exposure, when the frequency of AMPA receptor-mediated spontaneous excitatory post-synaptic currents are increased (58).

Caffeine supplementation could present a significant protective effect against $\mathrm{MeHg}$ toxicity with glutamate transmission. However, IFN- $\gamma$-stimulated neuronal cells were less protected by caffeine in L-glutamine-containing medium. Nevertheless, under the co-stimulation of SH-SY5Y cells with glutamine and IFN- $\gamma$, caffeine decreased $\mathrm{MeHg}$-induced average oxidative stress by $50 \%$. Glutamate seems to be an indispensable mediator of the effects of both mercury-induced toxicity and caffeine. Our results are in accordance with the findings of Bagga et al, with respect to glutamatergic neuronal activity and neurotransmission. Caffeine provides only partial neuroprotection against mercury-induced toxicity in IFN- $\gamma$-stimulated SH-SY5Y dopaminergic neurons (56).
In conclusion, these data suggest that mercury-induced neuronal death may occur through glutamate-mediated excitotoxicity. Adenosine receptor blockade by caffeine in equivalent doses of daily coffee consumption reduced the vulnerability to mercury-induced oxidative stress in glutamine-containing medium. The IFN- $\gamma$ stimulation of SH-SY5Y dopaminergic neurons severely decreased cell viability and increased oxidative stress in glutamine-free medium despite caffeine supplementation. However, the addition of glutamine to the medium increased cell viability by $62 \%$ and reduced $\mathrm{MeHg}$-related oxidative stress intensity by $62 \%$ in the presence of $10 \mu \mathrm{M}$ caffeine. It can thus be concluded that the IFN- $\gamma$ stimulation of mercury-exposed dopaminergic neurons in neuroinflammatory diseases may diminish the neuroprotective effects of caffeine.

\section{Acknowledgements}

The study was partially supported by The Scientific and Technological Research Council of Turkey (no. 214S112). This study has been orally presented in the ' 35 th Winter-Workshop on Clinical, Chemical and Biochemical Aspects of Pteridines, February 23rd-26th, 2016, Innsbruck, Austria'.

\section{References}

1. Karimi R, Vacchi-Suzzi C and Meliker JR: Mercury exposure and a shift toward oxidative stress in avid seafood consumers. Environ Res 146: 100-107, 2016.

2. Clarkson TW and Magos L: The toxicology of mercury and its chemical compounds. Crit Rev Toxicol 36: 609-662, 2006.

3. Lohren H, Blagojevic L, Fitkau R, Ebert F, Schildknecht S, Leist $\mathrm{M}$ and Schwerdtle T: Toxicity of organic and inorganic mercury species in differentiated human neurons and human astrocytes. J Trace Elem Med Biol 32: 200-208, 2015.

4. Aschner M, Yao CP, Allen JW and Tan KH: Methylmercury alters glutamate transport in astrocytes. Neurochem Int 37: 199-206, 2000

5. Brookes N: In vitro evidence for the role of glutamate in the CNS toxicity of mercury. Toxicology 76: 245-256, 1992.

6. Liu W, Xu Z, Deng Y, Xu B, Wei Y and Yang T: Protective effects of memantine against methylmercury-induced glutamate dyshomeostasis and oxidative stress in rat cerebral cortex. Neurotox Res 24: 320-337, 2013

7. Xu F, Farkas S, Kortbeek S, Zhang F-X, Chen L, Zamponi GW and Syed NI: Mercury-induced toxicity of rat cortical neurons is mediated through N-Methyl-D-Aspartate receptors. Mol Brain 5: 30, 2012.

8. Biessels GJ: Caffeine, diabetes, cognition, and dementia. J Alzheimers Dis 20 (Suppl 1): S143-S150, 2010.

9. Brown SJ, James S, Reddington M and Richardson PJ: Both A1 and A2a purine receptors regulate striatal acetylcholine release. J Neurochem 55: 31-38, 1990.

10. Penna S, Pocino M, Marval MJ, Lloreta J, Gallardo L and Vila J: Modifications in rat testicular morphology and increases in IFN-gamma serum levels by the oral administration of subtoxic doses of mercuric chloride. Syst Biol Reprod Med 55: 69-84, 2009.

11. Kempuraj D, Asadi S, Zhang B, Manola A, Hogan J, Peterson E and Theoharides TC: Mercury induces inflammatory mediator release from human mast cells. J Neuroinflammation 7: 20, 2010.

12. Liu YJ, Guo DW, Tian L, Shang DS, Zhao WD, Li B, Fang WG, Zhu L and Chen YH: Peripheral T cells derived from Alzheimer's disease patients overexpress CXCR2 contributing to its transendothelial migration, which is microglial TNF-alpha-dependent. Neurobiol Aging 31: 175-188, 2010.

13. Man SM, Ma YR, Shang DS, Zhao WD, Li B, Guo DW, Fang WG, Zhu L and Chen YH: Peripheral T cells overexpress MIP-1alpha to enhance its transendothelial migration in Alzheimer's disease. Neurobiol Aging 28: 485-496, 2007.

14. Minogue AM, Jones RS, Kelly RJ, McDonald CL, Connor TJ and Lynch MA: Age-associated dysregulation of microglial activation is coupled with enhanced blood-brain barrier permeability and pathology in APP/PS1 mice. Neurobiol Aging 35: 1442-1452, 2014 
15. Popko B, Corbin JG, Baerwald KD, Dupree J and Garcia AM: The effects of interferon-gamma on the central nervous system. Mol Neurobiol 14: 19-35, 1997.

16. Lee M, McGeer E and McGeer PL: Neurotoxins released from interferon-gamma-stimulated human astrocytes. Neuroscience 229: 164-175, 2013.

17. Podolsky MA, Solomos AC, Durso LC, Evans SM, Rall GF and Rose RW: Extended JAK activation and delayed STAT1 dephosphorylation contribute to the distinct signaling profile of CNS neurons exposed to interferon-gamma. J Neuroimmunol 251: 33-38, 2012.

18. Seifert HA, Leonardo CC, Hall AA, Rowe DD, Collier LA, Benkovic SA, Willing AE and Pennypacker KR: The spleen contributes to stroke induced neurodegeneration through interferon gamma signaling. Metab Brain Dis 27: 131-141, 2012.

19. Kulkarni A, Ganesan P and O'Donnell LA: Interferon Gamma: Influence on Neural Stem Cell Function in Neurodegenerative and Neuroinflammatory Disease. Clin Med Insights Pathol 9 (Suppl 1): 9-19, 2016.

20. Mizuno T, Zhang G, Takeuchi H, Kawanokuchi J, Wang J, Sonobe Y, Jin S, Takada N, Komatsu Y and Suzumura A: Interferon-gamma directly induces neurotoxicity through a neuron specific, calcium-permeable complex of IFN-gamma receptor and AMPA GluR1 receptor. FASEB J 22: 1797-1806, 2008.

21. Lee J, Kim SJ, Son TG, Chan SL and Mattson MP: Interferon-gamma is up-regulated in the hippocampus in response to intermittent fasting and protects hippocampal neurons against excitotoxicity. J Neurosci Res 83: 1552-1557, 2006

22. Zhang Y, Werling U and Edelmann W: SLiCE: A novel bacterial cell extract-based DNA cloning method. Nucleic Acids Res 40: $\mathrm{e} 55,2012$

23. Rosano GL and Ceccarelli EA: Recombinant protein expression in Escherichia coli: Advances and challenges. Front Microbiol 5: 172,2014

24. Robichon C, Luo J, Causey TB, Benner JS and Samuelson JC: Engineering Escherichia coli BL21(DE3) derivative strains to minimize $E$. coli protein contamination after purification by immobilized metal affinity chromatography. Appl Environ Microbiol 77: 4634-4646, 2011.

25. Abe R, Kudou M, Tanaka Y, Arakawa T and Tsumoto K: Immobilized metal affinity chromatography in the presence of arginine. Biochem Biophys Res Commun 381: 306-310, 2009.

26. Becker A and Soliman KFA: The role of intracellular glutathione in inorganic mercury-induced toxicity in neuroblastoma cells. Neurochem Res 34: 1677-1684, 2009.

27. Björkman L, Lundekvam BF, Laegreid T, Bertelsen BI, Morild I, Lilleng P, Lind B, Palm B and Vahter M: Mercury in human brain, blood, muscle and toenails in relation to exposure: An autopsy study. Environ Health 6: 30, 2007.

28. Cysneiros RM, Farkas D, Harmatz JS, von Moltke LL and Greenblatt DJ: Pharmacokinetic and pharmacodynamic interactions between zolpidem and caffeine. Clin Pharmacol Ther 82 $54-62,2007$.

29. Spyridopoulos I, Fichtlscherer S, Popp R, Toennes SW Fisslthaler B, Trepels T, Zernecke A, Liehn EA, Weber C, Zeiher AM, et al: Caffeine enhances endothelial repair by an AMPK-dependent mechanism. Arterioscler Thromb Vasc Biol 28: 1967-1974, 2008

30. Toimela T,MäenpääH,Mannerström Mand TähtiH:Development of an in vitro blood-brain barrier model-cytotoxicity of mercury and aluminum. Toxicol Appl Pharmacol 195: 73-82, 2004.

31. Mosmann T: Rapid colorimetric assay for cellular growth and survival: Application to proliferation and cytotoxicity assays. J Immunol Methods 65: 55-63, 1983.

32. Miranda KM, Espey MG and Wink DA: A rapid, simple spectrophotometric method for simultaneous detection of nitrate and nitrite. Nitric Oxide 5: 62-71, 2001.

33. Engin AB: Investigation of the effect of $\mathrm{C} 1 \mathrm{Q}$ and complement regulatory protein $\mathrm{CD} 59$ on the $\mathrm{SH}-\mathrm{SY} 5 \mathrm{Y}$ cell viability in hyperglycemic conditions (unpublished PhD thesis). Gazi University, Institute of Health Sciences, 2015

34. Sappington DR, Siegel ER, Hiatt G, Desai A, Penney RB, Jamshidi-Parsian A, Griffin RJ and Boysen G: Glutamine drives glutathione synthesis and contributes to radiation sensitivity of A549 and H460 lung cancer cell lines. Biochim Biophys Acta 1860: 836-843, 2016.

35. Tamarappoo BK, Raizada MK and Kilberg MS: Identification of a system $\mathrm{N}$-like $\mathrm{Na}(+)$-dependent glutamine transport activity in rat brain neurons. J Neurochem 68: 954-960, 1997.

36. Bröer S and Brookes N: Transfer of glutamine between astrocytes and neurons. J Neurochem 77: 705-719, 2001.

37. Su TZ, Campbell GW and Oxender DL: Glutamine transport in cerebellar granule cells in culture. Brain Res 757: 69-78, 1997.
38. Conti F and Minelli A: Glutamate immunoreactivity in rat cerebral cortex is reversibly abolished by 6-diazo-5-oxo-L-norleucine (DON), an inhibitor of phosphate-activated glutaminase. J Histochem Cytochem 42: 717-726, 1994.

39. Pow DV and Crook DK: Direct immunocytochemical evidence for the transfer of glutamine from glial cells to neurons: Use of specific antibodies directed against the d-stereoisomers of glutamate and glutamine. Neuroscience 70: 295-302, 1996.

40. Magistretti PJ and Pellerin L: Cellular mechanisms of brain energy metabolism and their relevance to functional brain imaging. Philos Trans R Soc Lond B Biol Sci 354: 1155-1163, 1999.

41. Roberg BA, Torgner IA and Kvamme E: Kinetics of a novel isoform of phosphate activated glutaminase (PAG) in SH-SY5Y neuroblastoma cells. Neurochem Res 35: 875-880, 2010.

42. D'Alessandro G, Calcagno E, Tartari S, Rizzardini M, Invernizzi RW and Cantoni L: Glutamate and glutathione interplay in a motor neuronal model of amyotrophic lateral sclerosis reveals altered energy metabolism. Neurobiol Dis 43 346-355, 2011.

43. Kaur P, Aschner M and Syversen T: Glutathione modulation influences methyl mercury induced neurotoxicity in primary cell cultures of neurons and astrocytes. Neurotoxicology 27: 492-500, 2006.

44. Franco JL, Posser T, Dunkley PR, Dickson PW, Mattos JJ, Martins R, Bainy AC, Marques MR, Dafre AL and Farina M: Methylmercury neurotoxicity is associated with inhibition of the antioxidant enzyme glutathione peroxidase. Free Radic Biol Med 47: 449-457, 2009.

45. Yoshida E, Abiko Y and Kumagai Y: Glutathione adduct of methylmercury activates the Keap1-Nrf2 pathway in SH-SY5Y cells. Chem Res Toxicol 27: 1780-1786, 2014.

46. Ferré S, Karcz-Kubicha M, Hope BT, Popoli P, Burgueño J, Gutiérrez MA, Casadó V, Fuxe K, Goldberg SR, Lluis C, et al: Synergistic interaction between adenosine A2A and glutamate mGlu5 receptors: Implications for striatal neuronal function. Proc Natl Acad Sci USA 99: 11940-11945, 2002.

47. Morton-Jones RT, Cannell MB and Housley GD: Ca2+ entry via AMPA-type glutamate receptors triggers $\mathrm{Ca} 2+-$ induced $\mathrm{Ca} 2+$ release from ryanodine receptors in rat spiral ganglion neurons. Cell Calcium 43: 356-366, 2008

48. Vyleta NP and Smith SM: Fast inhibition of glutamate-activated currents by caffeine. PLoS One 3: e3155, 2008

49. Liu X, Smith BJ, Chen C, Callegari E, Becker SL, Chen X, Cianfrogna J, Doran AC, Doran SD, Gibbs JP, et al: Evaluation of cerebrospinal fluid concentration and plasma free concentration as a surrogate measurement for brain free concentration. Drug Metab Dispos 34: 1443-1447, 2006.

50. Daly JW, Butts-Lamb P and Padgett W: Subclasses of adenosine receptors in the central nervous system: Interaction with caffeine and related methylxanthines. Cell Mol Neurobiol 3: 69-80, 1983.

51. Björklund O, Kahlström J, Salmi P, Ogren SO, Vahter M, Chen JF, Fredholm BB and Daré E: The effects of methylmercury on motor activity are sex- and age-dependent, and modulated by genetic deletion of adenosine receptors and caffeine administration. Toxicology 241: 119-133, 2007.

52. Feng S, Xu Z, Liu W, Li Y, Deng Y and Xu B: Preventive effects of dextromethorphan on methylmercury-induced glutamate dyshomeostasis and oxidative damage in rat cerebral cortex. Biol Trace Elem Res 159: 332-345, 2014

53. Zeidán-Chuliá F, Gelain DP, Kolling EA, Rybarczyk-Filho JL, Ambrosi P, Terra SR, Pires AS, da Rocha JB, Behr GA and Moreira JC: Major components of energy drinks (caffeine, taurine, and guarana) exert cytotoxic effects on human neuronal SH-SY5Y cells by decreasing reactive oxygen species production. Oxid Med Cell Longev 2013: 791795, 2013.

54. Abreu RV, Silva-Oliveira EM, Moraes MFD, Pereira GS and Moraes-Santos T: Chronic coffee and caffeine ingestion effects on the cognitive function and antioxidant system of rat brains Pharmacol Biochem Behav 99: 659-664, 2011.

55. Kalda A, Yu L, Oztas E and Chen JF: Novel neuroprotection by caffeine and adenosine $\mathrm{A}(2 \mathrm{~A})$ receptor antagonists in animal models of Parkinson's disease. J Neurol Sci 248: 9-15, 2006.

56. Bagga P, Chugani AN and Patel AB: Neuroprotective effects of caffeine in MPTP model of Parkinson's disease: A (13)C NMR study. Neurochem Int 92: 25-34, 2016.

57. Titze-de-Almeida SS, Lustosa CF, Horst CH, Bel ED and Titze-de-Almeida R: Interferon Gamma potentiates the injury caused by MPP(+) on SH-SY5Y cells, which is attenuated by the nitric oxide synthases inhibition. Neurochem Res 39: 2452-2464, 2014.

58. Vikman KS, Owe-Larsson B, Brask J, Kristensson KS and Hill RH: Interferon-gamma-induced changes in synaptic activity and AMPA receptor clustering in hippocampal cultures. Brain Res 896: 18-29, 2001. 